\title{
D202 コジェネレーション用セラミックガスタービンの研究開発
}

\section{Reserch and Development of Ceramic Gas Turbines for Co-generation}

\author{
市川 善浩（川崎重工業）＼cjkstart巽＼cjkstart哲男（川崎重工業）
}

Yoshihiro ICHIKAWA, Kawasaki Heavy Industries, Kawasaki-cho 1-1, Akashi

Tetsuo TATSUMI, Kawasaki Heavy Industries

\begin{abstract}
This paper describes a summary of the research and development program (FY1988-1998) of $300-\mathrm{kW}$ class ceramic gas turbine (CGT302). This program has been promoted as a part of the New Sunshine Project funded by the Ministry of International Trade and Industry (MITI). The CGT302 has successfully accomplished the following that: i) it achieved $42.1 \%$ thermal efficiency at a turbine inlet temperature (TIT) of $1,396^{\circ} \mathrm{C}$, ii) it obtained $31.7 \mathrm{ppm}$ NOx emissions $\left(\mathrm{O}_{2}=16 \%\right)$ within the regulated value by the law at $1,350^{\circ} \mathrm{C}$ TIT and iii) it accumulated more than two thousand hours operation at $1,200^{\circ} \mathrm{C}$ TIT. Also, this paper presents an overview and a current status of the development program (FY 1999-2003) of 8,000-kW class hybrid gas turbine (HGT) in which both metal and ceramics are used in parts of high temperature to achieve high thermal efficiency and low
emissions.
\end{abstract}

Key Words: Ceramics, Gas Turbine, Energy Saving, Thermal Efficiency, Design

\section{1. 緒曹}

一般に, ガスタービンはディーゼルエンジンなど他の同 出力エンジンと比較して小型かつ軽量であり, 低 NOx, 低騒音という観点から地球環境に優しい原動機として大い に期待されている．しかし，小出力機では，熱効率が低い という最大の弱点を有している.

ガスタービンの熱効率向上を図るために，1988 年度か ら 1998 年度にかけて通産省工業技術院のニューサンシャ イン計画の一環として, セラミックガスタービン (CGT) の研究開発が行われた. 開発目標は, セラミックスをガス タービンに適用し，無冷却でタービン入口温度 (TTT) を $1,350^{\circ} \mathrm{C}$ まで高くすることで $42 \%$ という世界最高レベルの 熱効率を狙うと共に，排ガス特性を法令基準値以内に収め るというものである. 川崎重工業は，このプロジェクトの 2 軸再生式セラミックガスタービン（CGT302）の開発を担 当し, 最終年度には目標を達成することができた.

この研究成果から高効率セラミックガスタービンの赛用 化への気運が高まり，昨年度から 5 ケ年計画として産業用 コージェネレーション実用技術開発が新たに通産省工業技 術院の下で開始され，川崎重工業はこれに参画している。 本開発は, 高効率・低公害が期待できる $8,000 \mathrm{~kW}$ 級の, 高 温部にセラミックスと金属の双方を用いたハイブリッドガ スタービン（HGT）を用いて，高効率エネルギー利用の促
進による $\mathrm{CO}_{2}$ 排出削減等に資することを目的としている. 開発目標は, タービン入口温度 $1,250^{\circ} \mathrm{C}$ で熱効率 $34 \%$ 以上, 運転時間 4,000 時間, 排ガス特性が法令基準值以内という ものである.

本稿では, 1998 年度に終了した CGT302 の研究成果のま とめを述べると共に, 現在行われている HGT の研究概要 および開発進捗状況を述べる.

\section{CGT302 の概 要}

CGT302 はコージェネレーション用の 2 軸再生式ガスタ ービンである. CGT302 の諸元を Table 1に示す. また, エ ンジンのカットモデルおよびセラミック部品を Fig. 1, Fig. 2 に示す．圧縮機は単段, 燃焼筒は単缶, タービンはガス ジェネレータタービン, パワータービン各々単段である. セラミック適用部分は燃焼筒からパワータービンまでで, セラミック材料は窒化ケイ素を採用している. 熱交換器は 金属製の伝熱式プレートフィン型である.

一般に，ガスタービンはタービン入口温度を上げると熱 効率は向上するが，小型ガスタービンでは翼冷却が困難な ことからタービン入口温度を上げられないため, 熱効率は あまり高くない. CGT302 ではこれを解決するべく無泠却 セラミックス翼を採用している. 
Table 1 Specifications of CGT302

\begin{tabular}{|c|c|c|}
\hline Item & Unit & Target \\
\hline Maximum Power & $\mathrm{kW}$ & 300 \\
\hline Thermal Efficiency & $\%$ & 42 \\
\hline Turbine Inlet Temperature & ${ }^{\circ} \mathrm{C}$ & 1,350 \\
\hline Air Flow Rate & $\mathrm{kg} / \mathrm{s}$ & 0.94 \\
\hline Pressure Ratio & - & 8 \\
\hline GGT Speed & $\mathrm{rpm}$ & 64,000 \\
\hline PT Speed & $\mathrm{rpm}$ & 47,800 \\
\hline Compressor Efficiency & $\%$ & 82 \\
\hline Turbine Efficiency (GGT+PT) & $\%$ & 85.5 \\
\hline Heat Exchanger Efficiency & $\%$ & 82 \\
\hline
\end{tabular}

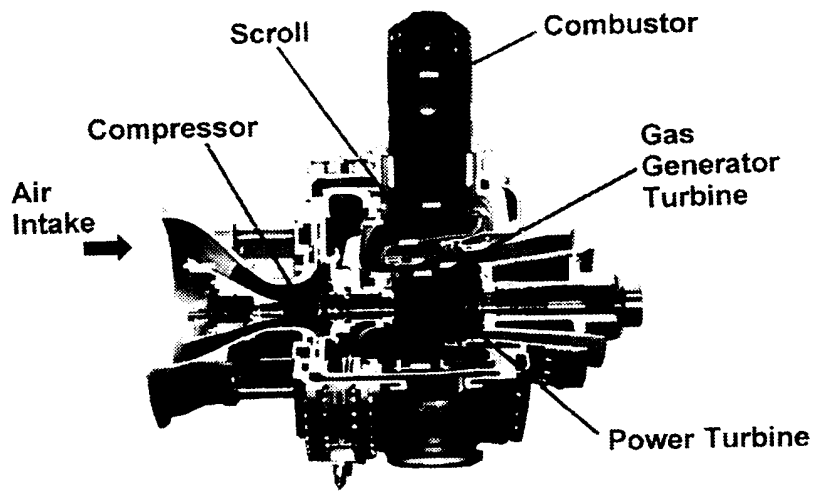

Fig. 1 Cut Model of CGT302
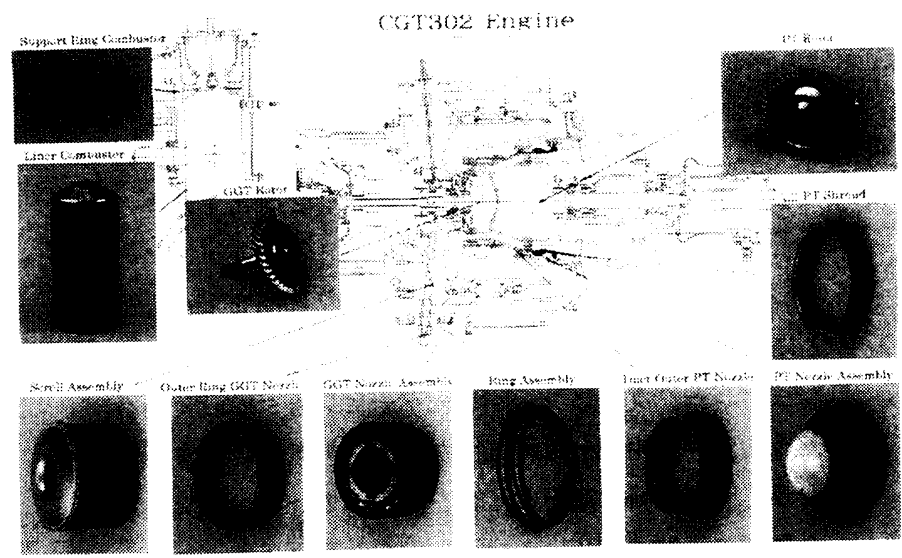

Fig. 2 Ceramic Components of CGT302

\section{CGT302 のセラミック構造}

セラミックスは金属材料に比べ熱膨張係数がかなり小 く, 非常に脆いという特性を持っている.これらの特性に 対し，CGT302 では FRC（綫維強化セラミックス）による
締結一体化構造，セラミックバネによる弾性支持構造や相 互独立支持構造を採用している.

モノリシックセラミックスは耐熱性, 而摩耗性に優れて いるが，大型複雑形状部品では熱応力による損傷を起こし やすい，一方で FRC はある程度の靭性, 変形能を備えて いるため熱応力による損傷を起こしにくいが, 耐酸化性, 而摩耗性に劣る。そこで Fig. 3 に示すような各々の長所を 生かした FRCによる締結一体化構造を開発した。

金属の熱膨張係数はセラミックスに比べかなり大きい。 また，セラミックスの固定に際し，ボルト等による直接的 な固定はへルツ応力によりセラミックスが損傷しやすい. これらの問題を解決するため, セラミックバネによる弾性 支持構造を採用した. さらに，構造部材の熱変形による部 品間の干渉を避けるため, 部品相互に支持をさせない1 所支持による相互独立支持構造を採用した。Fig. 4 に CGT302の弾性支持構造, 相互独立支持構造の例を示す.
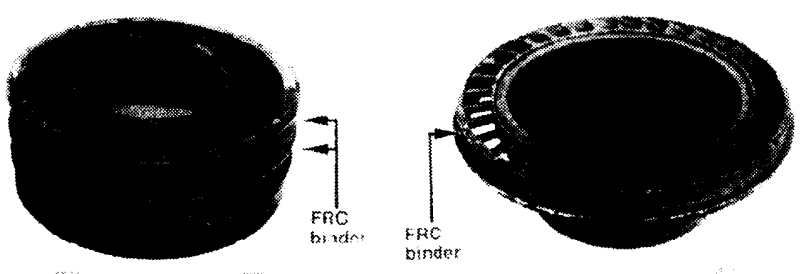

Fig. 3 FRC-Binding Turbine Nozzles

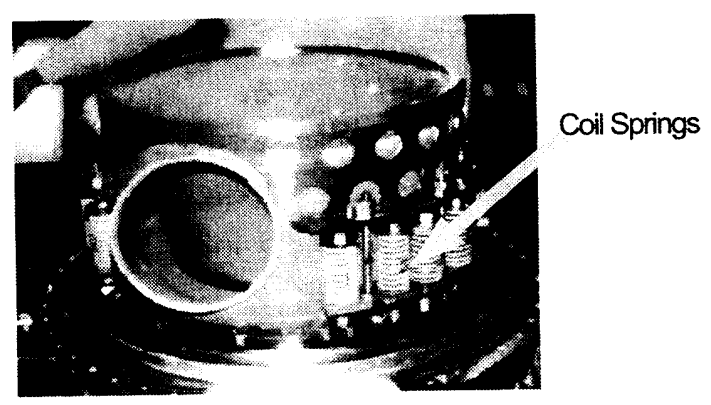
Wave Rings

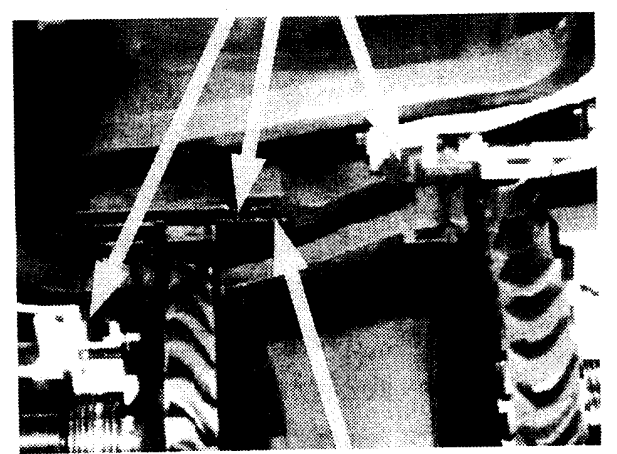

Piston Rings

Fig. 4 Independent and Elastic Supporting by Ceramic Springs 


\section{CGT302 の研究成果}

エンジン運転研究の研究成果について以下にまとめる.

\section{（1）性能試験}

本プロジェクトでは，性能試験を(1)金属製基本型 GT (TTT $=900^{\circ} \mathrm{C}$ 級) (2)基本型 CGT（ $\mathrm{TIT}=1,200^{\circ} \mathrm{C}$ 級）(3)パイロ ット CGT（TTT $=1,350^{\circ} \mathrm{C}$ 級）の 3 ステップに分けて実施し た. Fig. 5 に各ステップでの代表的な性能計測デー夕を示 す.このような性能改良を経て, 最終的には $\mathrm{TTT}=1,396^{\circ} \mathrm{C}$ において出力 $322 \mathrm{~kW}$, 熱効率 $42.1 \%$ と最終目標を達成した。 この熱効率は既存の従来型ガスタービンと比較して，出力 が数十 MW クラスの最大級ガスタービンにも匹敵する画 期的な成果といえる.

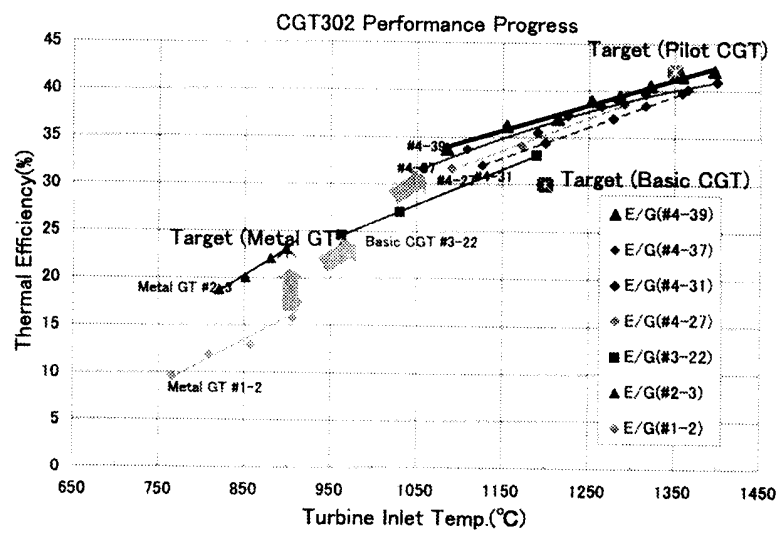

Fig. 5 Performance Progress of CGT302

\section{（2）予混合希薄燃焼による排ガス特性試検。}

一般に，NOx 排出量はタービン入口温度が上昇するに つれて飛躍的に上昇する. CGT302 は $\mathrm{TTT}=1,350^{\circ} \mathrm{C}$ と従来型 ガスタービンに比べ非常に高いため，NOx 排出量はかな り増加する．そこで Fig. 6 に示すような予混合希薄燃焼方 式を採用することにより問題解決を図り， TTT $=1,350^{\circ} \mathrm{C} に$ おいて目標の $70 \mathrm{ppm}\left(\mathrm{O}_{2}=16 \%\right)$ 以下を大きく下回る 31.7ppmを達成した.

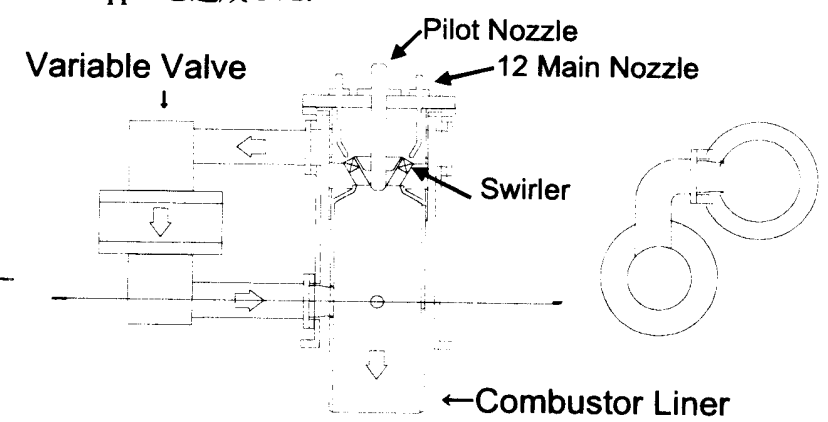

\section{(3) 長時間運転試験}

セラミック材料の長時間信頼性の検証を行うため，実用 化レベルの TTT $=1,200^{\circ} \mathrm{C}$ で目標 1,000 時間の長時間運転試験 を害施した. 試験当初はDSS（Daily Start Stop）で運転し， 安定性を確認した上でWSS（Weekly Start Stop）に移行する 運転とした。運転試験は，500 時間以上経過したところで， 3 度のガスジェネレータタービンの損傷により，同一組立 部品での目標 1,000 時間を到達することはできなかった。 しかし， 3 回目の損傷時に生き残った燃焼器ライナを引き 続き運転に供試し，目標の 1,000 時間到達したところで試 験を打ち切った。 その燃焼器ライナに関し, 材料的に問題 ないことを確認した。長時間運転試験の総累積運転時間は, $\mathrm{TIT}=1,200^{\circ} \mathrm{C}$ で 2,117 時間に及ぶものである. Fig. 7 に運転中 のガスタービンおよび操作パネルを示す.
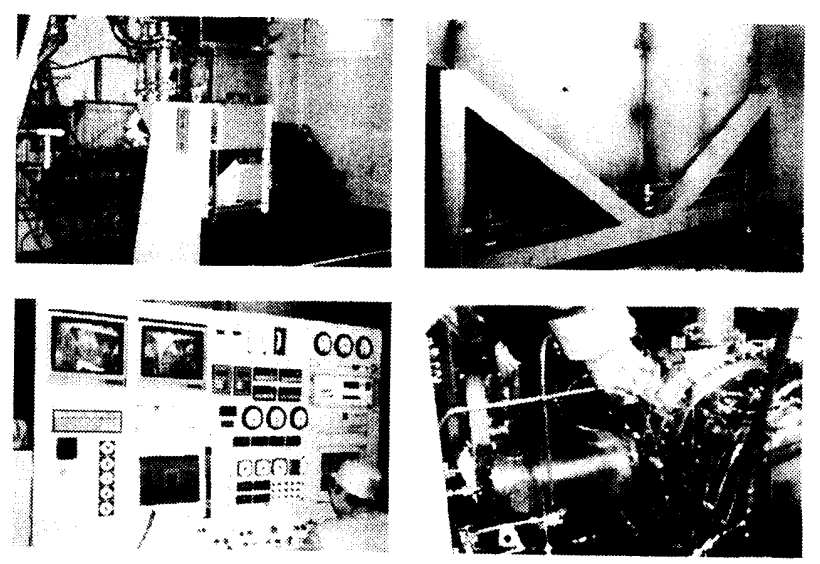

Fig. 7 Gas Turbine and Operation Panel under Operation

\section{HGT の概要}

上述したような CGT302 の研究成果を基に, 昨年度から 産業用コージェネレーション実用技術開発（HGT）が通産 省工業技術院のプロジェクトとして開始されている。 Table 2 に開発目標, Table 3 に開発スケジュールを示す.

Table 2 Targets of HGT

\begin{tabular}{|c|c|}
\hline Item & Target \\
\hline Output Power & $8,000 \mathrm{~kW}$ class \\
\hline Thermal Efficiency & $34 \%$ or higher \\
\hline Turbine Inlet Temperature & $1,250^{\circ} \mathrm{C}$ ctass \\
\hline Operation Time & 4,000 hours \\
\hline Emission Characteristics & Within regulations by the law \\
\hline
\end{tabular}

Fig. 6 Premixed Lean Bum Combustor of CGT302 
Table 3 Development Schedule of HGT

\begin{tabular}{|c|c|c|c|c|c|}
\hline & 1999 & 2000 & 2001 & $\begin{array}{l}2002 \\
\text { Interim } \\
\text { Evaluation } \\
\nabla\end{array}$ & $\begin{array}{l}2003 \\
\text { Final } \\
\text { Evaluation }\end{array}$ \\
\hline \multicolumn{6}{|l|}{$\begin{array}{l}\text { (1) Development and } \\
\text { Evaluation tests of } \\
\text { Ceramic Components }\end{array}$} \\
\hline \\
\hline \\
\hline \multirow{2}{*}{\multicolumn{6}{|c|}{$\begin{array}{l}\text { Soundness and Reliability } \\
\text { Basic Design } \\
\text { Detailed Design }\end{array}$}} \\
\hline & & & & & \\
\hline $\begin{array}{l}\text { Manufacture of engine } \\
\text { Study of the Operation }\end{array}$ & & & & & \\
\hline (3) General Investigation of & & & & & \\
\hline the System & & & & & \\
\hline
\end{tabular}

HGT は川崎重工業製 7,000kW 級 M7A-02 をベースに, Fig. 8 に示すように燃焼器ライナから第 1 段タービンノズ ルまでをセラミック化したものである．セラミック材料は CGT302 と同じく窒化ケイ素を採用している．HGT のセラ ミック適用部品は CGT302 用燃焼器ライナと比較してサイ ズ的には大差がないことから，CGT302 のセラミック部品 製造技術を応用でき，開発リスクを最小限に押さえている。 また, 本研究開発はセラミック部品の健全性・信頼性を検 証することに主眼を置いているため, 極力金属側の設計変 更を最小限とするよう圧縮機の設計変更はせず，タービン のみを設計変更することとした。

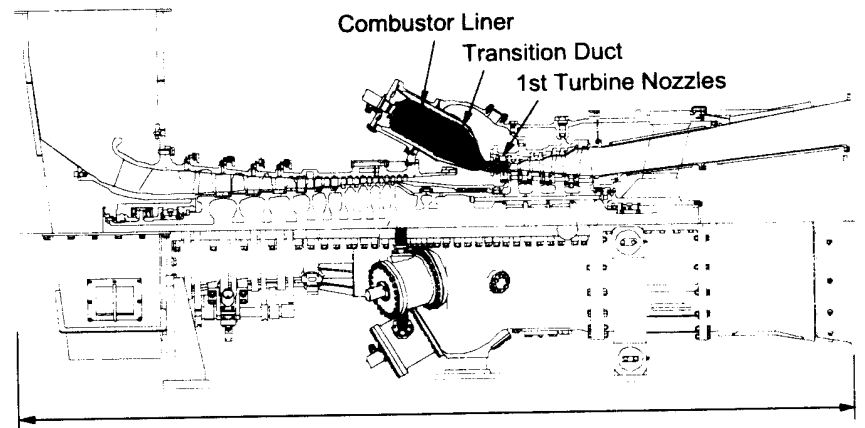

Fig. 8 Applied Parts of Ceramics on Based Gas Turbine M7A-02

\section{HGTの開発進路状況}

現在までの HGT の開発進捗状況について以下に述べる.

\section{(1)セラミック部品の設計}

タービン入口温度の高温化に伴い, 燃焼器ライナ, トラ ンジションダクト，第 1 段タービンノズルなど高温静止部 品を従来の金属から耐熱性に優れたセラミックスに設計変 更するため, 数種類の部品形状案を作成し，1 種に絞った. Fig. 9 に設計試作した主要セラミック部品を示す.
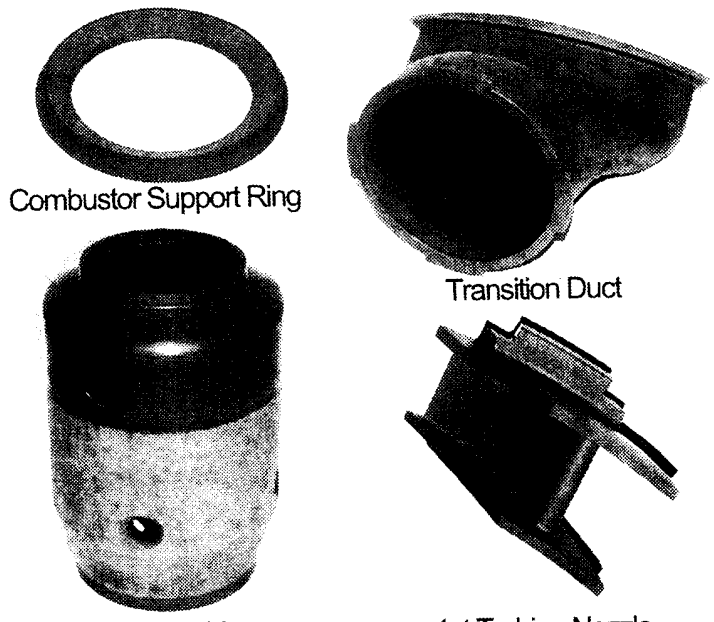

Combustor Liner

1st Turbine Nozzle

Fig. 9 Ceramic Components of HGT

第 1 段タービンノズルの耐熱衝撃性を検証するため, 定 常運車時の熱応力解析, 起動時およびシャットダウン時の 非定常熱応力解析を行らた.この際，ノズル表面の温度分 布は熱流動解析により求める手法を採用した。最も忘力的 に厳しかったのはシャットダウン時で, 最大主态力がシャ ットダウン後 $7 \mathrm{sec}$ 経過時で $124 \mathrm{MPa}$, 最小主応力がシャッ トダウン後 $11 \mathrm{sec}$ 経過時で-122MPa となった。これは材料 強度に照らして，特に問題ないレベルである．Fig. 10 にこ れらの熱応力分布を示す.

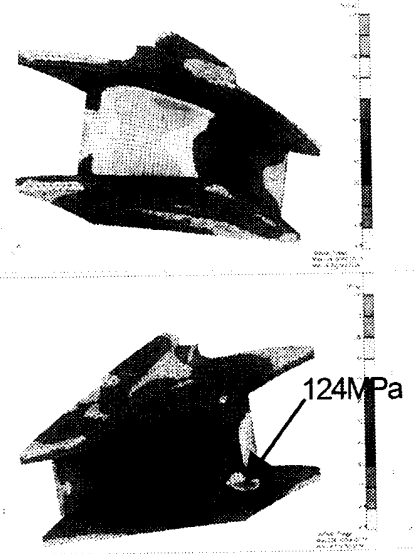

After $7 \mathrm{sec}$

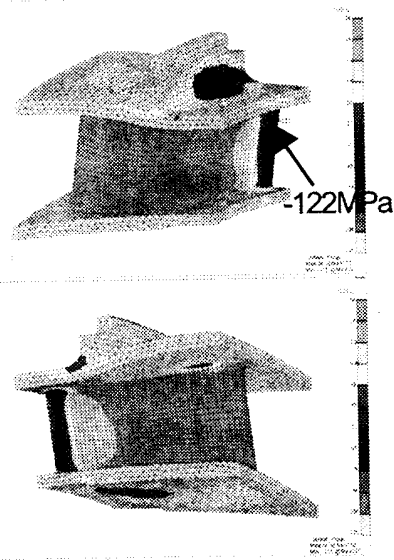

After $11 \mathrm{sec}$
Fig. 10 Thermal Stress Distribution at Shut Down

\section{(2)セラミック部品支持構造の開発}

金属とセラミックスとでは熱膨張差が大きく異なること やセラミックスは脆性材料であることは寸でに述べたが， HGT でもセラミックス特有の特性を考慮する必要がある ため, CGT302 で培った弾性支持構造, 相互独立支持構造 の技術を踏襲して HGT の構造設計を行った。しかし， HGT は水平 2 分割構造を採用しているため, CGT302 で有 
効であった FRC による締結一体化構造, ピストンリング 等の一体型シールリングなどが適用できない，そこで, 空 気漏れを最小限とするような迷路構造, 分割型シールリン グと扇形バネを併用したシール構造を新たに開発した。 Fig. 11 にGT のセラミック部品周辺構造の一例を示す.

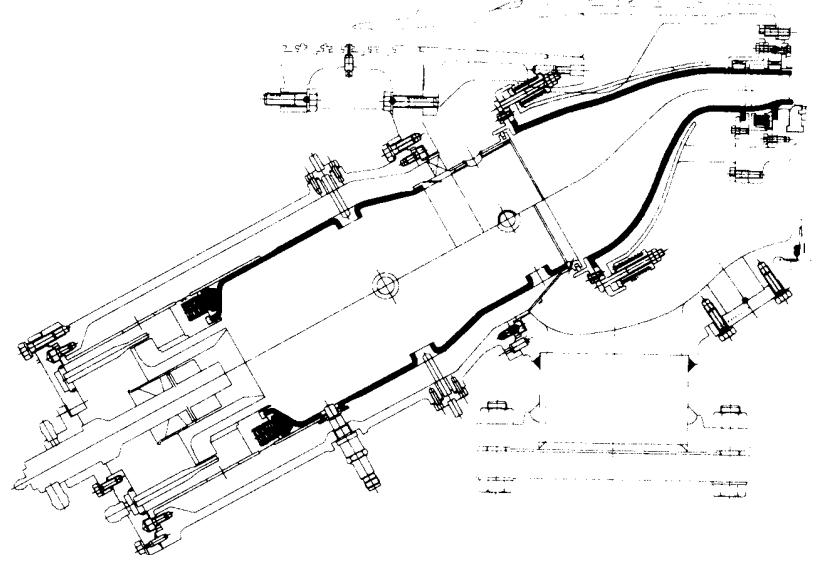

Fig. 11 Fringe Structure of Ceramics

\section{(3)タービン部の設計}

タービン入口温度の高温化に伴い, タービンを通過する 体積流量が約 6\%増加する. しかし，ベースガスタービン はタービン部でチョークするように設計されているため, タービン流量が増加した分, 計画流量が確保できず目標エ ンジン性能を満足させることが不可能となる．そこでター ビンのスロート面積を広げ，大流量側ヘマッチング点をず らすという方法を採用し，圧縮機の断熱効率の高い領域で 運転できるように配慮した。

タービン部の各段の状態量（温度, 圧力）を数值計算に より概算し, 材質, 翼型, 冷却構造等改良項目の抽出を行 った. 第 3 段タービン動翼について, ベースガスタービン と同じく無冷却翼としたため, 高温域においてクリープ強 度に優れている単結晶合金（SC； Single Cristal）を採用し た. 単結晶合金は, 異方性材料でかつ, ベースガスタービ ンで採用している等方晶材（CC；Conventional Casting）に 比べ比重が大きくなるため, 遠心応力解析および振動解析 を実施し，特に問題ないことを確認した。 Fig. 12 に遠心応 力解析結果を示す. また, 第 4段タービン動静翼について, ベースガスタービンの翼型のままとすると第 4段タービン 動翼出口のガス流出角やガス流出速度が大きく変化し, 所 要の排気ディフューザ性能を確保できなくなるため, 翼型 を新規設計することとした。

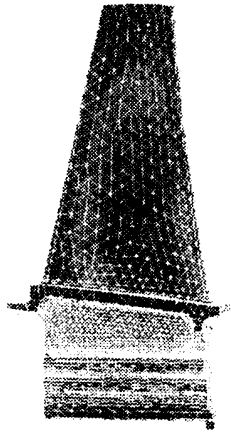

SC (HGT)
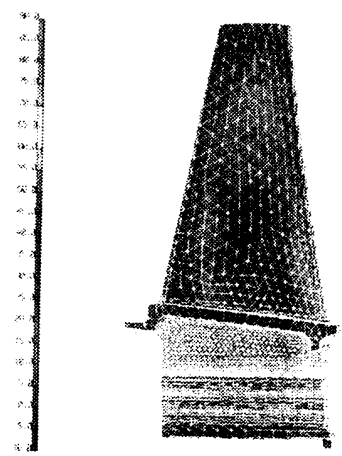

CC (Base)
Fig. 12 Centrifugal Stress Distribution of 3rd Tarbine Blade

\section{(4)低 NOx 蜗烧器の開㚘}

ベースガスタービンの Dry Low Emission (DLE) 燃焼器 を基にして低 NOx 燃焼器の基本設計を実施した. Fig. 13 に燃焼器断面図を示す. 燃焼器ライナをセラミックスにす ることにより, 従来のフィルム冷却孔を廃止し, 新たにラ イナ下流部に希釈孔を設けた. また，タービン入口温度の 上昇に伴い燃料流量が増加するため, 予混合希薄燃焼用 ジアルスワーラ出口の幅を拡大し, 局所の空燃比を従来と 同程度となるようにした. 基本的な構造は CGT302 の構造 技術を踏襲している.

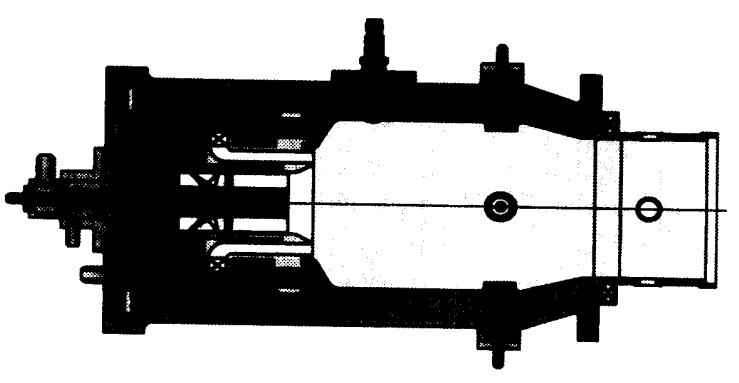

Fig. 13 Cross Section of HGT DLE Combustor

\section{(5)セラミック評洒試跙}

\section{(1)セクタ圾検}

セラミック部品を適用したエンジン運転試験に先立ち, セラミック部品と金属部品間の相互干涉やセラミック部品 の支持機能等, 構造的観点に立った設計の妥当性の検証, 材料的観点及び部品設計の観点に立ったセラミック部品の 而熱衝撃性の検証が必要である.これらの検証を行うため, セラミック部品周辺構造部分を抽出したセク夕試験機の設 計を行い，現在製作中である。セク夕試験機は，エンジン の燃焼器とメインハウジング（静止部品）を流用し、セラ ミック部品を適用した燃焼器から第 1 段タービンノズルま でのエンジン模擬試験装置である. ただし，空気源の能力 に制約があるため, 燃焼器 1 缶分（周上 1/6）の供試構造 とした. Fig. 14 にセクタ試験機の全体図を示す. 


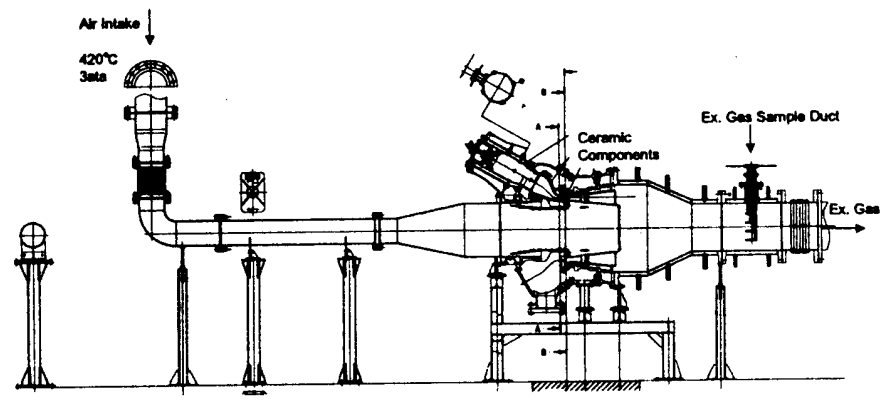

Fig. 14 Overall of Sector Tester

\section{参考文献}

1) I. Takehara, T. Tatsumi and Y. Ichikawa, "Summary of CGT302 Ceramic Gas Turbine Reserch and Development Program", ASME Paper 2000-GT-644 (2000).

2) T. Abe, T. Sugiura, S. Okunaga, K. Nojima, Y. Tsutsui and T. Matsunuma, "Research and Development of Practical Industrial Cogeneration Technology in Japan", ASME Paper 2000-GT-655 (2000).

\section{(2)セラミック暖焉試検}

水蒸気を含む高温燃焼ガス曝露環境下でセラミック部材 の表面層が減肉するという事例が国内外で報告されており， HGT でも同様な現象が起こる可能性は否定できない，そ こで評価試験による確認と対策を検討するため, セラミッ ク曝露試験を実施することとした. 現在, 曝露試験機の設 計を行い，製作中である. Fig. 15 にセラミック曝露試験機 の供試体部を示す. 試験内容として, 温度・圧力・水蒸気 分圧・ガス流速などの各パラメータがセラミック部品の肉 厚堿少に及ぼす影響を評価する予定である.

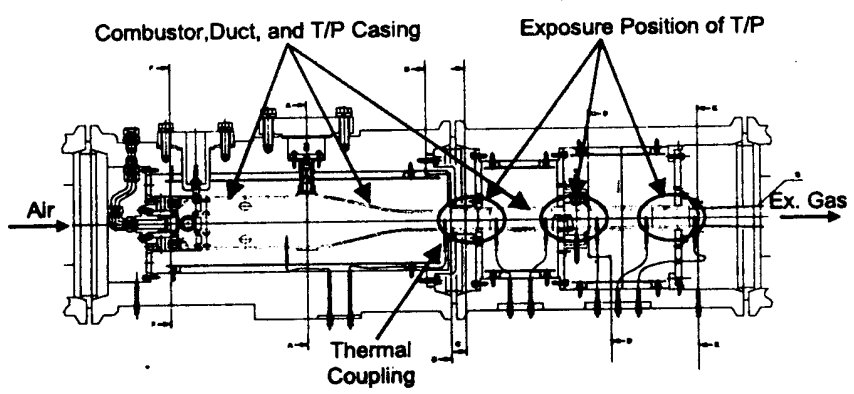

Fig. 15 Test Section of Ceramic Exposure Tester

\section{7. 結 言}

セラミックガスタービンの研究開発において, CGT302 では，TIT $=1,396^{\circ} \mathrm{C}$ で出力 $322 \mathrm{~kW}$, 熱効率 $42.1 \%$ を達成，ま た TIT $=1,350^{\circ} \mathrm{C}$ で NOx 排出量 $31.7 \mathrm{ppm}\left(\mathrm{O}_{2}=16 \%\right)$ を達成し, セラミックスがガスタービンの構造部材として成り立つと 共に性能向上や環境保全に非常に有効であることを証明し た. HGTでは, CGT302で不十分であったセラミックスの 長時間の健全性・信頼性を検証し，セラミックガスタービ ンの実用化促進に向けて研究開発を進めている.この HGT が近年高まっている省資源化，環境問題などに対応 した低燃費, 低公害, 燃料多様性等の優れた特性を持つ次 世代原動機として世に貢献できるよう尽力していく所存で ある。 